\title{
Identifying Effective Determinants of New Service Design and Development Process in Service Organizations
}

\author{
Abbass Dinarvandi \\ M.A Student, Faculty of Entrepreneurship, University of Tehran \\ Email: Dinarvandy@ut.ac.ir \\ Mohammad Reza Meigounpoory \\ Corresponding author: Assistant Professor, University of Tehran, Tehran, Iran. \\ Email: meigounpoory@ut.ac.ir \\ DOI: $\quad 10.6007 /$ IJARBSS/v3-i11/340 URL: http://dx.doi.org/10.6007/IJARBSS/v3-i11/340
}

\begin{abstract}
Fierce competition and more demanding needs for customer oriented services have been instigated service organizations to apply new approaches for service design and delivery. Private banking systems are one of the most important parts of service organizations. The efforts in grasping more financial resources by private banks versus governmental banks as well as growth in customers' needs for effective services have enforced private banking managers for using new service design and development process in Iranian private bank systems. New Service design and Development (NSD) process providing the lower cost and higher benefit methods for creation of competitive advantage in global banking systems. In this paper the effective determinants in new service development process of Iranian private Banks has been identified. The qualitative data was collected through interviews. The methodology is adapted from in-depth interviews with academic experts and managers of private banking systems until theoretical saturation state achieved. The gathered data was analyzed using axial and open coding methods. The results shows that the NSD process Iranian private banking systems is consist of four main stages and 28 axial factors and 52 secondary factors. The main factors are includes of analysis\& new concept development, design, pilot and launch, development stages. Eventually, the results of this paper can be used for the new services development process in the private banking systems of a competitive environment at the other countries.
\end{abstract}

Keywords: Banking services, New Service Development, private banking systems, Innovation, Paper Type: Research Paper

\section{Introduction}

Recently there has been many academic interest of new service development. NSD involves developing offerings such as financial and banking services; health care; communications and information services; leisure and hospitality services; travel services; facilities management and 
educational services; legal and consulting services. Offerings can be sold either to consumers or to businesses, and sometimes to both, (Johne, et al.,1997). A large share of innovative efforts in business is related to the development of new services (OECD, 2000; Howells, 2000). Despite its significance, many service firms still struggle with their innovative efforts. Authors like Cook et al. (1999), Den Hertog (2000), Avlonitis et al. (2001), Gadrey et al.(1995) and Chase et al. (1998) have stressed that innovation in services can be related to changes in various dimensions. Some examples include innovation in the service concept, the client interface, the delivery system and technological options. Innovation in the service concept includes changes in the characteristics of the service itself. This dimension is most widely recognized. In financial services, for instance, new service development (NSD) is usually organized in a sequential manner (Vermeulen, 2001; Vermeulen \& Dankbaar, 2002). NSD is one of the best systematic approaches for innovation development in service organization specially in banking systems. The main goal of this paper is the finding the effective determinants in new service development process of Iranian private Banks.

\section{Literature Review:}

Nowadays, since the service sectors in developing and developed countries have the highest growth in GDP and employment, the significance of service sectors is increasing remarkably. Since 1970 portion of services in GDP of developing countries has increased from $20 \%$ to $70 \%$. Service sector is the greatest part of economy in all of world countries,(World Bank, 2008), for example, service sectors in Iran has $40 \%$ proportion of national GDP(OECD,2013). Services are key factors for economy and industry development. for example service industries of U.S.A in 2007, has contained of 75\% GDP, (Linberg \& Monaldo, 2008). Moreover, ventures' tendency toward offering new services to customers has converted new service development (NSD) management to one of the main concerns of businesses (Johnson et al., 2000; Menor et al., 2002). However, NSD remains among the least studied and understood topics in the service management literature despite the existence of many research and models on product development, especially in recent years (Menor et al., 2002). As a result, considering the importance of NSD process in rapid changing environment, it seems critical for much more in-depth research to be done in the field.

Several issues remain to be addressed in investigation of NSD process for service organizations. First, researchers have often used the words 'new service development' and 'new product development' interchangeably, highlighting the need for a working definition of NSD (Johne and Storey 1996). Second, the some published literature has been concerned with the development of new financial services and it is only in recent years that researchers have begun to address issues concerned with the wide span of services offered today (Johne and Storey 1996). Third, services differ from products in terms of a number of key characteristics, (Stevens, E. 2002). As the economies world over become more service oriented, firms recognize the need to compete on the basis of new service offerings (Bitnet, Brown, and Meuter, 2000). However, NSD cannot be the same as the development of a tangible product (Kelly \& Storey, 2000), and it could get more comprehensive and complicated because of it being concerned with developing new service products (Johne and Storey, 1998). Cadwallader et al. (2010) stated that the success of NSD is defined by measures which refer to the NSD project itself, for example by measuring its duration or cost, as well as the success of 
the developed and implemented service, expressed through financial or market factors. In fact, new service development relies on tasks that are difficult to understand or solve and anticipate a change in customer needs (Matthing et al., 2004). According to Johnson et al. (2000), new service development is defined as " the process of offering a service not previously available to customer, and results from the addition of offerings, radical changes in the service delivery process, or incremental improvements to existing service package or delivery processes that customers perceive as being new". According to Cooper and Edgett (1996), the rate of failure in businesses trying to offer new service is approximately 50\%. Alinvi \& Barbi, (2007), are of view that customers preferences change on a constant basis, and organizations adjust in order to meet these changes to remain competitive and profitable. Rao, (2008), attempted to understand how service firms actually innovate. He found that all the private life insurance companies have a formal New Service Development (NSD) unit and top executive and R\&D department participate in creation of new services. Although all the companies are aware of the importance of customer involvement, the results shows that there is potential for increasing customer involvement in NSD process. NSD has not only become an important competitive factor in many industries (Menor et al., 2002), but has also raised the interest of researchers in the fields of innovation, marketing and operations management (De Brentani, 1989, Thwaites,1992, Cooper et al., 1994, Johne and Storey, 1998, Storey and Kelly, 2001, Menor and Roth, 2007). Therefore, creation and development of service innovation thorough NSD process has the great significance in service organizations. In fact, using NSD process models has a vital role in meeting customer 'needs and improving quality in service design process. Meigounpoory et al. (2011), study the high prevalence of chronic diseases in Iran and the high expenses resulting from inadequate health services such as nutrition counseling. Results of this paper identified the effective factors in NSD process in nutrition counseling field for creating value and competitive advantage. Consequently, huge expenses, and the customers' displeasure at not gaining adequate value, reveal the importance of identifying effective determinants in NSD process of private banking systems. Table - 1 displays the results of some studies in this field.

Table - 1: The effecting factors of NSD process in the literature

\begin{tabular}{|c|c|}
\hline Authors & Identified factor(s) \\
\hline Drew, A., 1995 & Training and education in NSD process \\
\hline $\begin{array}{c}\text { Nijhof et al, 2002 } \\
\text { Hellström \& Hellström, } \\
2002\end{array}$ & focuses on some particular sectors \& Financial \\
& \\
\hline
\end{tabular}




\begin{tabular}{|c|c|}
\hline $\begin{array}{c}\text { Cook et al., } 1999 \\
\text { Den Hertog, } 2000 \\
\text { Avlonitis et al, } 2001 \\
\text { Gadrey et al, } 1995 \\
\text { and Chase et al, } 1998\end{array}$ & innovation in services \\
\hline De Brentani, 2001-2000 & Innovation process in firms \\
\hline Kelly \& Storey, 2000 & beneficial new service development \\
\hline Johnson et al., 2000 & $\begin{array}{l}\text { Service nature, Project synergy, NSD process } \\
\text { type, Service market characteristics, Innovation } \\
\text { culture }\end{array}$ \\
\hline Cooper \& de Brentani, 1991 & Customer involvement Service delivery \\
\hline Bardhan et al., 2007 & System and Process design \\
\hline Van de Ven, 1986 & $\begin{array}{l}\text { The people-related characteristics the NSD } \\
\text { process }\end{array}$ \\
\hline Cadwallader et al.,2010 & $\begin{array}{l}\text { the success of NSD is defined by measures which } \\
\text { refer to the NSD project itself, for example by } \\
\text { measuring its duration or cost }\end{array}$ \\
\hline Meigounpoory, et al.,2013 & $\begin{array}{l}\text { Effective factors in NSD process in nutrition } \\
\text { counseling business }\end{array}$ \\
\hline $\begin{array}{c}\text { Shabankareh, N., } \\
\text { Meigounpoory M.R.,., } 2013\end{array}$ & $\begin{array}{c}\text { Conceptual model of new service development } \\
\text { process in Iranian governmental banks }\end{array}$ \\
\hline
\end{tabular}

Johnson et al. (2000) suggested a model describing the new service development process that can present four main stages with twelve tasks having to be done to launch a new service. These four stages are design, analysis, development, and launch as the following: 


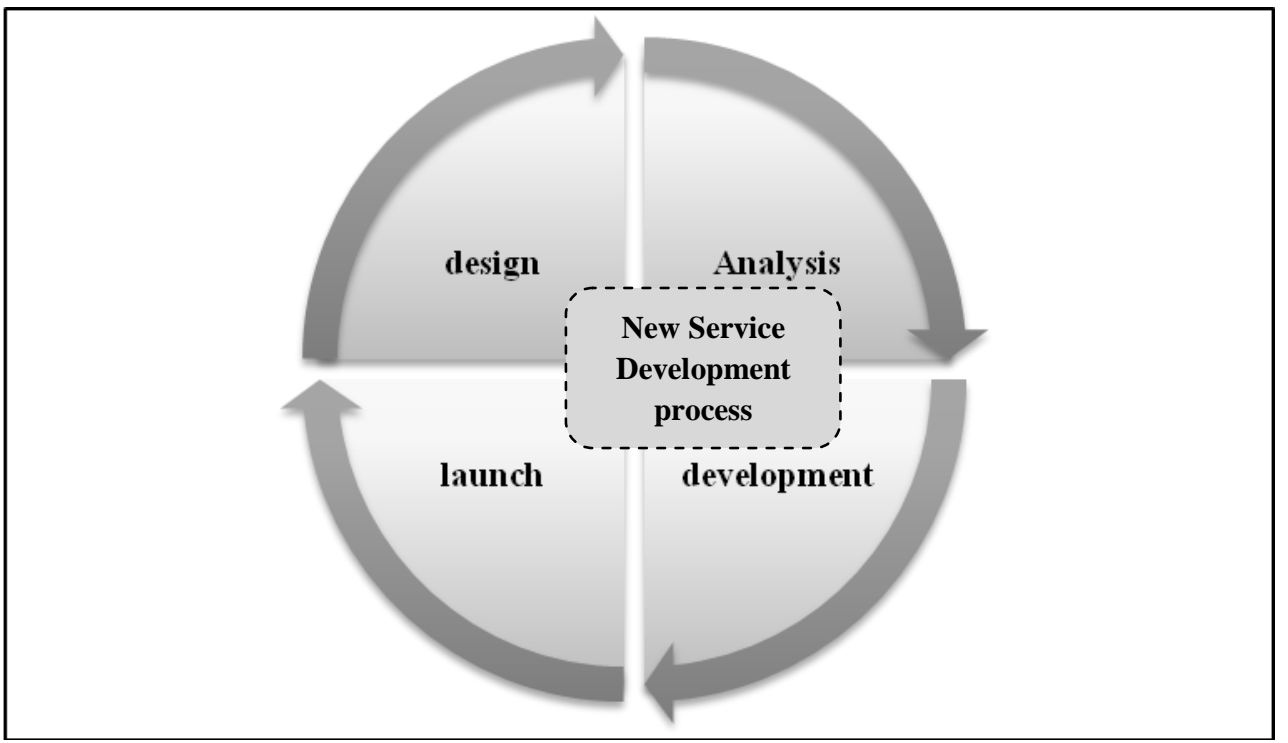

Figure1. New service development process based on Johnson et al.(2000)

\section{Research Methodology}

This research was implemented as a qualitative study, which involved the collection of data thorough face to face interviews. As a principle, the targeted sampling covered the academic experts and managers of private systems banking. Case of study has been focused on the private Bank of Iran, like Pasargad, Saman, etc. The sampling approach that was used is known as snowballing. Using this approach, the researchers first searched an adequate expert, and through his/her interview and recommendations obtained a list of experts as potential study participants. In the majority of qualitative studies, sample size should generally follow the concept of saturation (Glaser \& Strauss, 1967). In the present study saturation was reached after 18 interviews. The whole interviews were recorded and converted to transcripts. According to the method of Strauss and Corbin (1999), the data were analyzed using open and axial coding. Codes form the basis for later aggregation into concepts, in open coding. The aim of open coding is to begin the unrestricted labeling of all data and assign conceptual codes to each outstanding incident within the data (Strauss, 1987). Axial coding always follows open coding, and identifies relationships between open codes for the purpose of developing core codes (Strauss and Corbin, 1990). Statistical analysis of the research indicates that the respondents 'demographics of the participants were consist of $28.5 \%$ women and $71.5 \%$ men. Figure 1 shows the distribution of the respondents 'demographics. 
Figure - 2: distribution of the participants 'demographics based on academic degree and gender

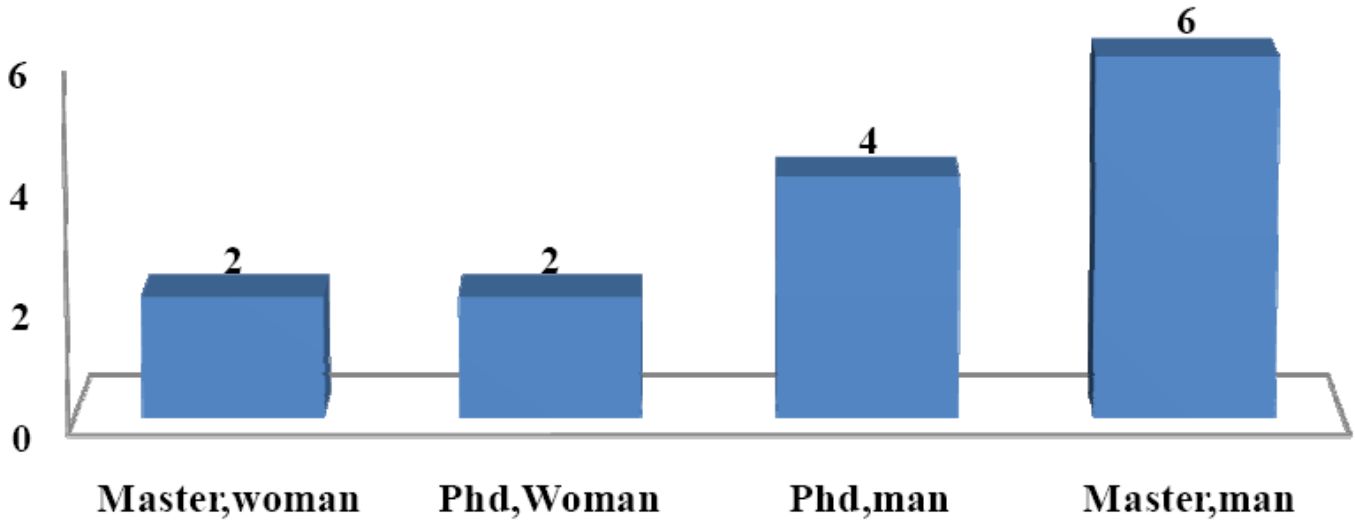

\section{Results}

In order to finding the factor affecting on new service development process in Iranian private Banks, the coding results were compared, discussed, and modified for any probable discrepancies. The attained final factors are shown in Table (2)-(5).

Table - 2: Results of the qualitative study, Effective Determinants of New Service Development process in Iranian private Banks- New Concept Development \& Analysis stage

\begin{tabular}{|c|c|c|c|}
\hline Concept & Index & Category & Frequency \\
\hline \multirow{10}{*}{ 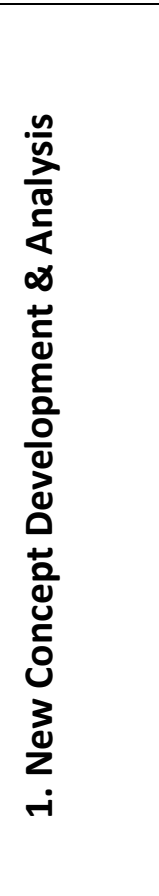 } & \multirow{4}{*}{ SWOT analysis } & Weaknesses of bank & 12 \\
\hline & & Strengths of bank & 11 \\
\hline & & Identifying opportunities & 14 \\
\hline & & Evaluating of Threats & 7 \\
\hline & \multirow{6}{*}{$\begin{array}{l}\text { New Concept } \\
\text { Development }\end{array}$} & New service development strategies & 12 \\
\hline & & new service Interdisciplinary team & 11 \\
\hline & & Mission statement of new service & 6 \\
\hline & & Customer needs identification & 12 \\
\hline & & $\begin{array}{l}\text { New Concept generation for service } \\
\text { innovation }\end{array}$ & 12 \\
\hline & & Concept testing & 7 \\
\hline
\end{tabular}




\begin{tabular}{|c|c|c|}
\hline & $\begin{array}{c}\text { Evaluation of Concept } \\
\text { (Technical, Market and financial } \\
\text { analysis) }\end{array}$ & 14 \\
\hline & Development of the concept & 7 \\
\hline & Selecting of new concept & 12 \\
\hline & Preparation of the final protocol & 7 \\
\hline & Project Management Plan & 12 \\
\hline & Project approval & 11 \\
\hline \multirow{6}{*}{$\begin{array}{l}\text { Business } \\
\text { Analysis }\end{array}$} & $\begin{array}{l}\text { Matching of business and new service } \\
\text { development strategy }\end{array}$ & 12 \\
\hline & $\begin{array}{c}\text { Social and Cultural Analysis for new } \\
\text { service delivery }\end{array}$ & 7 \\
\hline & Economic Analysis & 13 \\
\hline & $\begin{array}{c}\text { Legal Analysis for new service } \\
\text { development }\end{array}$ & 14 \\
\hline & Political Propulsion Analysis & 12 \\
\hline & Entrepreneurial environment analysis & 11 \\
\hline
\end{tabular}

Table - 3: Results of the qualitative study, Effective Determinants of New Service Development process in Iranian private Banks- service design stage

\begin{tabular}{|c|c|c|c|}
\hline Concept & Index & Category & Frequency \\
\hline \multirow{5}{*}{ 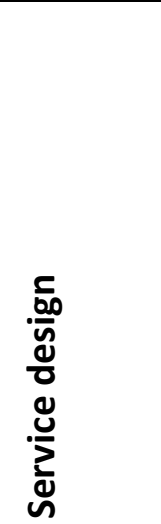 } & \multirow{2}{*}{$\begin{array}{c}\text { Architecture design of services in } \\
\text { private bank }\end{array}$} & Platform design & 4 \\
\hline & & Portfolio Design Service & 11 \\
\hline & \multirow{3}{*}{ Modeling of service process } & $\begin{array}{l}\text { design of service } \\
\text { Algorithm }\end{array}$ & 12 \\
\hline & & $\begin{array}{lll}\text { Design of } & \text { service } \\
\text { delivery } & & \end{array}$ & 11 \\
\hline & & Design of Process and & 8 \\
\hline
\end{tabular}




\begin{tabular}{|c|c|c|}
\hline & players & \\
\hline \multirow{5}{*}{ Design for excellence } & $\begin{array}{l}\text { Design of testing and } \\
\text { evaluation }\end{array}$ & 11 \\
\hline & $\begin{array}{l}\text { Design for standardize } \\
\text { the rules }\end{array}$ & 12 \\
\hline & $\begin{array}{l}\text { Design for compliance } \\
\text { with security rules }\end{array}$ & 10 \\
\hline & $\begin{array}{l}\text { Design for compliance } \\
\text { with legal rules }\end{array}$ & 9 \\
\hline & $\begin{array}{l}\text { Design for flexibility of } \\
\text { service }\end{array}$ & 12 \\
\hline Test and evaluation of design & $\begin{array}{c}\text { Test and evaluation of } \\
\text { design }\end{array}$ & 10 \\
\hline $\begin{array}{c}\text { Confirmation of NSD team and } \\
\text { R\&D managers }\end{array}$ & $\begin{array}{c}\text { Confirmation of NSD } \\
\text { team and R\&D } \\
\text { managers }\end{array}$ & 11 \\
\hline Design of Training and learning & $\begin{array}{l}\text { Learning NSDP in top } \\
\text { management level of } \\
\text { bank }\end{array}$ & 7 \\
\hline NSD process & $\begin{array}{l}\text { Training NSD between } \\
\text { staff, employee and } \\
\text { managers }\end{array}$ & 6 \\
\hline
\end{tabular}

Table - 4: Results of the qualitative study, Effective Determinants of New Service Development process in Iranian private Banks -Pilot \&Launch stage

\begin{tabular}{|l|l|l|l|}
\hline Concept & Index & Category & Frequency \\
\hline \multirow{2}{*}{} & Select Location of piloting & space & 9 \\
\cline { 3 - 4 } & & Local infrastructure & 10 \\
\cline { 3 - 4 } & & Proportion of new service & 11 \\
\cline { 2 - 4 } & Resources estimation & development team & \\
\cline { 3 - 4 } & & Funds & 11 \\
\cline { 3 - 4 } & & Where to buy supplies (space) & 11 \\
\hline
\end{tabular}




\begin{tabular}{|c|c|c|}
\hline \multirow[t]{3}{*}{ Pre-Pilot of services } & $\begin{array}{l}\text { Test system (by outside } \\
\text { experts team) }\end{array}$ & 9 \\
\hline & Feedback analysis & 8 \\
\hline & Fixing system defects & 11 \\
\hline Launch a pilot of service & $\begin{array}{l}\text { Piloting new service in a } \\
\text { sample branch of bank }\end{array}$ & 9 \\
\hline \multirow{2}{*}{$\begin{array}{l}\text { Design of marketing and sales } \\
\text { process }\end{array}$} & Customer participation & 12 \\
\hline & Competitor Analysis & 11 \\
\hline \multirow[t]{3}{*}{$\begin{array}{l}\text { Market testing and } \\
\text { evaluation }\end{array}$} & $\begin{array}{l}\text { Quality of information } \\
\text { received from a customer } \\
\text { perspective }\end{array}$ & 11 \\
\hline & $\begin{array}{l}\text { Received price information } \\
\text { from the customer } \\
\text { perspective }\end{array}$ & 11 \\
\hline & $\begin{array}{l}\text { Providing valuable information } \\
\text { received from the customer } \\
\text { perspective }\end{array}$ & 12 \\
\hline \multirow[t]{2}{*}{ Focus on Customers } & Existing Customers & 8 \\
\hline & Potential customers & 9 \\
\hline \multirow[t]{2}{*}{ Pilot revised before launch } & Cost and profit analysis & 12 \\
\hline & Market Analysis & 9 \\
\hline
\end{tabular}

Table - 5: Results of the qualitative study, Effective Determinants of New Service Development process in Iranian private Banks - Development stage

\begin{tabular}{|c|c|c|c|}
\hline Concept & Index & Category & Frequency \\
\hline \multirow{2}{*}{ 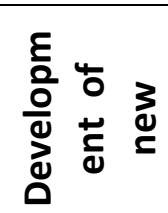 } & \multirow[t]{2}{*}{ Launched in national large-scale } & $\begin{array}{l}\text { Development in other } \\
\text { areas of the country }\end{array}$ & 12 \\
\hline & & Increase Specialist Staff & 10 \\
\hline
\end{tabular}




\begin{tabular}{|c|c|c|}
\hline & Developing new markets & 9 \\
\hline & $\begin{array}{l}\text { Complementary services } \\
\text { development }\end{array}$ & 12 \\
\hline \multirow[t]{2}{*}{$\begin{array}{l}\text { Service implementation in other } \\
\text { branches of bank }\end{array}$} & $\begin{array}{l}\text { Creation of new units in } \\
\text { other places }\end{array}$ & 10 \\
\hline & $\begin{array}{l}\text { Locate a special branch for } \\
\text { new service delivery }\end{array}$ & 11 \\
\hline \multirow{3}{*}{ Development of new strategies } & Customer Loyalty Strategy & 14 \\
\hline & Franchise & 6 \\
\hline & $\begin{array}{l}\text { Partnership with } \\
\text { international bank }\end{array}$ & 12 \\
\hline Branding business services & $\begin{array}{l}\text { Creation of national and } \\
\text { international brand in } \\
\text { service delivery }\end{array}$ & 10 \\
\hline \multirow{2}{*}{$\begin{array}{c}\text { Creation of international scope } \\
\text { of service delivery }\end{array}$} & $\begin{array}{l}\text { Development services in } \\
\text { international markets }\end{array}$ & 9 \\
\hline & $\begin{array}{ll}\text { Finding } & \text { International } \\
\text { partners } & \end{array}$ & 12 \\
\hline $\begin{array}{l}\text { Coordination between, new } \\
\text { services development processes } \\
\text { and organizational processes }\end{array}$ & $\begin{array}{l}\text { Reanalysis organization's } \\
\text { capabilities r and } \\
\text { Technology Trends }\end{array}$ & 10 \\
\hline The new definition of service & $\begin{array}{l}\text { The exact functionality of } \\
\text { services }\end{array}$ & 4 \\
\hline Project Time Management & Provide timely market & 5 \\
\hline $\begin{array}{l}\text { Test, evaluations and } \\
\text { Corrections }\end{array}$ & & 8 \\
\hline $\begin{array}{l}\text { Market and sale of new } \\
\text { services }\end{array}$ & $\begin{array}{l}\text { Service(product), } \\
\text { promotion, pricing, } \\
\text { positioning }\end{array}$ & 10 \\
\hline
\end{tabular}




\section{Discussion and Conclusion}

In this paper factors effecting on new service development process in Iranian Private Banks has been introduced. The qualitative data was collected through interviews. Results of this paper indicated that NSD Process in Iranian private banking systems is consist of four stages. The first stage of NSD process i.e. New Concept Development \& Analysis stage is consists of 3 axial factors and 22 secondary factors. Axial factors are consist of SWOT analysis, new concept development and business analysis according to coding techniques. Although in NSD model of Johnson et al. (2000), the first stage is called design and the second is analysis, findings of this study illustrate that in order to reduce the expenses of NSD process, it is more appropriate to develop of new concept, analyze the business, and then design the system process. The next stage of NSD process is service design that is contained of 6 axial factors and 14 secondary factors. Axial factors of service design are Architecture design of services in private bank, modeling of service process, Design for excellence, Test and evaluation of design and Confirmation of designed service by NSD team and R\&D managers and Design of Training and learning NSD process. Some secondary factors are Platform design, Portfolio Design Service, design of service Algorithm, , design of service delivery, design of process, design of training, , modular design, testing and evaluation, Design for standardize the rules, Design for compliance with security rules, Design for compliance with legal rules, and Designed for flexibility of service. According to data analysis, the third stage is pilot and launch having six main categories such as Select Location of piloting, Resources estimation, Pre-Pilot of services, Launch a pilot of service, Design of marketing and sales process, Market testing and evaluation, Focus on Customers and Pilot revised before launch. Additionally, findings of the interviews indicate that the last stage is development stage which is made up of Launched in national large-scale, Service implementation in other branches of bank, Development of new strategies, Branding business services, Creation of international scope of service delivery, Coordination between, new services development processes and organizational processes, The new definition of service Project Time Management, Test, evaluations and Corrections of services and Market and sale of new services. Table- 6 also shows this comparison of this paper results with other researchers in detail. 
Table - 6: The comparison of effective determinants of new Service Development process in Iranian private Banks with others

\begin{tabular}{|c|c|}
\hline $\begin{array}{lll}\text { Effective } & \text { Factors- } & \text { Present } \\
\text { Study } & & \end{array}$ & Effective Factors- other researchers Study \\
\hline New Concept Development & $\begin{array}{l}\text { Scheuing \& Johnson, } 1989 \\
\text { Edvardson \& Olson, } 1996 \\
\text { Meigounpoory\& Hashemi\& et al. } 2013 \\
\text { Meigounpoory, et al, } 2013\end{array}$ \\
\hline Business Analysis & $\begin{array}{l}\text { Scheuing \& Johnson, } 1989 \\
\text { Meigounpoory\& Hashemi\& et al. } 2013\end{array}$ \\
\hline SWOT & $\begin{array}{l}\text { Bullinger \& Schreiner, } 2006 \\
\text { Meigounpoory, et al, } 2013\end{array}$ \\
\hline Service design & $\begin{array}{l}\text { Edvardsson \& Johnson, } 1996 \\
\text { Bardhan et al., } 2007 \\
\text { Meigounpoory, et al, } 2013\end{array}$ \\
\hline Employee training & Scheuing \& Johnson, 1989 \\
\hline Pilot & $\begin{array}{l}\text { Scheuing \& Johnson, } 1989 \\
\text { Meigounpoory, et al, } 2013\end{array}$ \\
\hline Development of new service & $\begin{array}{l}\text { Scheuing \& Johnson, } 1989 \\
\text { Scheuing \& Johnson, } 1989 \\
\text { Meigounpoory, et al, } 2013\end{array}$ \\
\hline
\end{tabular}

As the Table 6 is shown, the results of this paper have been confirmed by other researchers. Finally the New conceptual model of New Service Development process in Iranian private Banks is shown in figure-3.

Figure-3. Conceptual model of New Service Development process in Iranian private Banks 


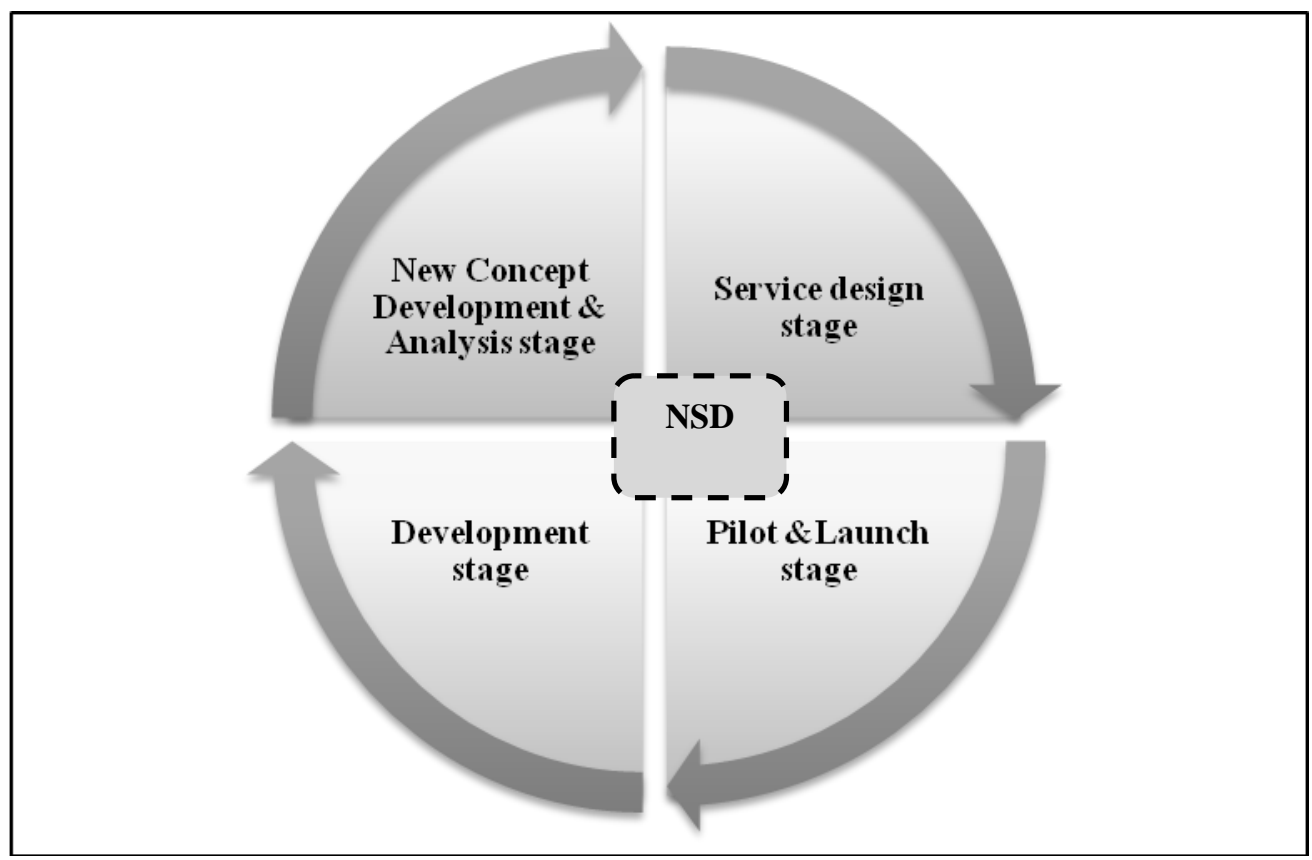

Furthermore, the comparison of the literature of NSD with the findings of present survey demonstrates that the results is confirmed by the studies of some previous authors such as Scheming and Johnson (1989), Edvardsson and Olson (1996), Bullinger and Schreiner (2006) and Bardhan et al. (2007). The results of this paper can be shows that the first stage of NSD process must starts with New Concept Development \& Analysis stage. Banking system's R\&D units must apply this stage when they are going to start new service development. This stage has low cost but high benefit for improvement of service delivery of banking systems. Table-2 can be used as outline for New Concept Development \& Analysis stage of NSD process. The second stage is service design and table- 3 is as a outline for design of new service in systematic approach. The other stages of NSD process are pilot\& launch and development stages and their outlines can be extracted from table-3 and table-4. The results of this paper can be implemented by R\&D centers of Iranian private banks. The new theoretical model of this paper can be used for the world private banking systems, especially for banking systems Middle East countries.

\section{REFERENCES}

Bullinger, Hans-Jörg, and Peter Schreiner (2006), Service Engineering: Ein Rahmenkonzept für die systematische Entwicklung von Dienstleistungen, Service Engineering, 53-84.

Bardhan, I. R., Krishnan, V. V. \& Lin, and S. (2007), Project performance and the enabling role of information Technology: An exploratory study on the role of alignment. Manufacturing and Service Operations Management, 9(1): 579-595. 
Cadwallader, S., Jarvis, C.B., Bitner M.J. and Ostrom, A.L. (2010), Frontline employee motivation to participate in service innovation implementation, Journal of the Academy of Marketing Science, 38(2), 219-239.

Cooper, R.G. \& U. de Brentani (1991), 'new industrial financial services: what distinguishes the winners', Journal of Product Innovation Management, Vol. 8 No. 2, pp. 75-90.

Cooper, R.G. \& S.J. Edgett (1999), Product development for the service sector. Lessons from market leaders, Cambridge, MA: Perseus Books.

Cooper, R. G. \& De Brentani, U. (1991), new industrial financial services: What distinguishes the winners, Journal of Product Innovation Management, 8(1), 75- 90.

Cooper, R. G., Easingwood, C. J., Edgett, S., Kleinschmidt, E. J. \& Storey, C. (1994) ,What distinguishes the top performing new products in financial services, Journal of Product Innovation Management, 11(1), 281-299.

Cooper R.G and Edgett S.J. (1996), Critical success factors for new financial services, Marketing Management, 5(3), 26-37.

Drew, S. (1995b), 'Strategic benchmarking: innovation practices in financial institutions', International Journalof Bank Marketing, Vol. 11 No. 1, pp. 4-16.

De Brentani, U. (1989), 'Success and failure in new industrial services', Journal of Product Innovation Management, Vol. 6, pp. 239-258.

De Brentani, U. (1993), 'the new product process in financial services: Strategy for success', International Journal of Bank Marketing, Vol. 11 No. 3, pp. 15-22.

De Brentani, U. (2001), 'Innovative versus incremental new business services: different keys for achieving success', Journal of Product Innovation Management, Vol. 18 No. 3, pp. 169-187.

De Brentani, U. Innovative versus incremental new business services: Different keys for achieving success. Journal of Product Innovation Management 2001; 18(1): 169-187.

Dolfsma, W. (2004), the Process of New Service Development: Issues of Formalization and Appropriability, ' ERIM Report Series Reference No. ERS-2004-051- ORG, 8 (Jun). Industries Journal, 2(4), 140-64.

Huete, L. \& A.V. Roth (1988), the industrialization and Span of Retail Banks' delivery systems, International

Journal of Operations and Production Management, Vol. 8, pp. 46-66

Johne, A. \& Storey, C. (1998), New service development: a review of the literature and annotated bibliography, European Journal of Marketing, 184-251.

Johnson, S.P., Menor, L.J., Roth, A.V., Chase, R.B. (2000), A critical evaluation of the new service development process: integrating service innovation and service design, In: Fitzsimmons, J.A., Fitzsimmons, M.J. (Eds.), New Service Development Creating Memorable Experiences. Sage Publications, 1-32.

Kelly, D., Storey, C. (2000), New service development: initiation strategies, International Journal of Services Industry Management, 1 (11), 45-62

Meigounpoory M. R, et al, (2013), Effective Factors In NSD Process Of Iranian Active ScienceBased Business in The Field of Nutrition Counseling, Far East Journal of Psychology and Business, Vol. 10 No. 1. 
Shabankareh N., Meigounpoory M. R, (2013), New conceptual models of New Service Development Process in Iranian governmental banking system, International journal of human resource and business, International journal of academic research in business and social science, August 2013, Vol. 3, No. 8,205-214.

Mohammad Alijani Shoki, Mohammadreza Meigounpoory, et al.,(2011), Providence of strategic decision making model, Technology Transfer Management with entrepreneurship approach, Crisis of developing countries"Case study :IRAN", ,Business and Management Review journal, vol.1,no. 3, 70-86.

Hengameh Rabiei, Mohammad Reza Meigounpoory, et al, Key Success Factors For Achiving Customers's Loyalty in e-smes: A study on impact of customer and e-business characteristics on e-loyalty in Iran, Contemporary Marketing Review Vol. 1(7) pp. 01 - 15, September, (2011).

Weerawardena J., McColl-Kennedy J. R. (2002), New Service Development and Competitive Advantage: A Conceptual Model, Australasian Marketing Journal, 10 (1), 2002. 